\title{
Atypical giant prolactinoma with frontal lobe manifestations
}

\author{
Muhammad Fahad Arshad, ${ }^{1}$ Maulee Arambewela, ${ }^{1,2}$ Miguel Debono ${ }^{1}$
}

'Diabetes and Endocrine Department, Sheffield Teaching Hospitals NHS Foundation Trust, Sheffield, UK

${ }^{2}$ Department of Medical Education and Health Sciences, University of Sri Jayawardenepura, Nugegoda, Sri Lanka

\section{Correspondence to} Dr Muhammad Fahad Arshad, dr.fahadarshad@live.com

Accepted 23 August 2018
Check for updates

(c) BMJ Publishing Group Limited 2018. No commercial re-use. See rights and permissions. Published by BMJ.

\begin{tabular}{l}
\hline To cite: Arshad MF, \\
Arambewela M, Debono M. \\
BMJ Case Rep Published \\
Online First: [please \\
include Day Month Year]. \\
doi:10.1136/bcr-2018- \\
226982 \\
\hline
\end{tabular}

\section{DESCRIPTION}

Prolactinomas having the diameter above $4 \mathrm{~cm}$ are termed 'giant prolactinomas'. ${ }^{2}$ Their incidence is approximately $2 \%-3 \%$ of all prolactinomas ${ }^{1}$. These are associated with very high prolactin concentration and numerous neurological sequelae, arising from their extension into surrounding structures. However, frontal lobe symptoms have not been reported frequently in the literature. ${ }^{3}$ These are more common in males with the male-to-female ratio of $9: 1{ }^{1}$ We report an atypical case of a giant prolactinoma that presented with frontal lobe symptoms but responded remarkably well to dopamine agonist treatment.

We present a case of a 65 -year-old woman who presented with progressively worsening short-term memory loss, confusion, mild intermittent headaches, increased somnolence, difficulty in walking due to unsteadiness and urine incontinence of 2 months' duration. There was a major change in behaviour and personality. On examination, she was confused with Montreal Cognitive Assessment score of $15 / 30$, loosing points mainly on verbal memory, fluency and orientation. She also had evidence of perseveration and positive pout reflex suggestive of frontal lobe impairment. Her visual fields were abnormal with bitemporal hemianopia. Limbs examination was normal with bilateral down going plantars. Her posture was stooped with shuffling gate. There was no history of spontaneous/ expressive galactorrhoea, and no previous history of infertility or subfertility. She was sterilised in her late 30 s and was on no contraception until the menopause in the late 40s.

She underwent an MRI scan of the brain that showed large multiloculated cystic masses bulging upwards into the suprasellar cistern, frontal horns of ventricles, third ventricle and frontal lobes (figure 1). Her prolactin levels were found to be very elevated at $280689 \mathrm{mIU} / \mathrm{L}$ (102-496). Surprisingly, apart from suppressed gonadotrophins, the rest of pituitary functions were entirely normal. She

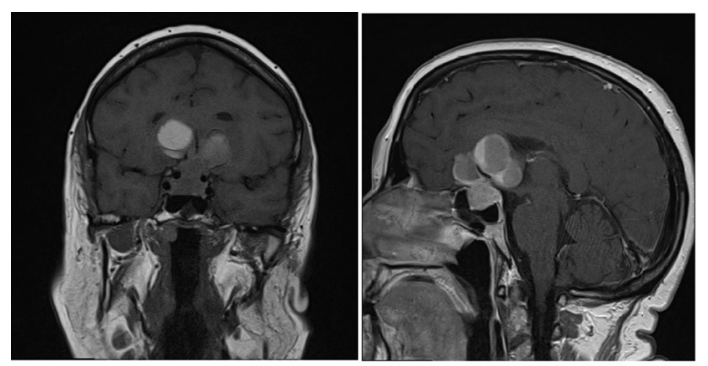

Figure 1 MRI scan at presentation.
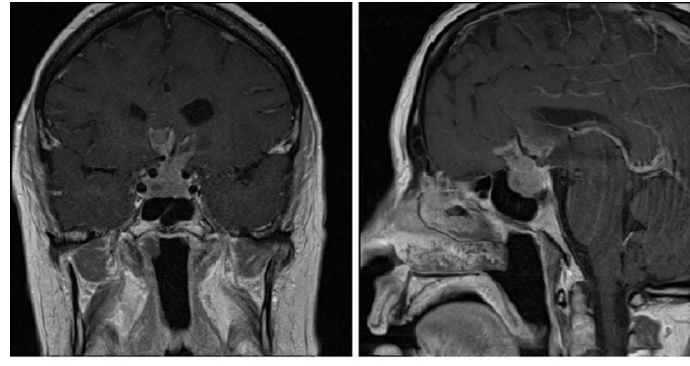

Figure 2 MRI scan 2.5 months later.

\section{Patient's perspective}

At first, I noticed that I had difficulty with my memory and was unable to remember what I was doing in a room and suffered from headaches. I felt drained with very little energy to get out of bed. At my worst, I was sleeping 16-18 hours a day and was unable to hold a conversation with my family or visitors.

After a month or so, my balance was getting worse and my vision had gotten blurry and narrowed. After this point, I have almost no recollection of what happened. My family described it a 'drifted along' and had to be cared for almost full time, many times falling asleep while eating and becoming incontinent.

I have a vague recollection of my admission to the hospital and early consultations. It is only after treatment started, I realised how poorly I was and the condition that I had been in I began to notice my symptoms easing but a new unpleasant nasal discharge which lasted a few weeks.

I now have my life back with all my symptoms gone or vastly improved. I would like to take this opportunity to thank everyone involved in my care and treatment for all their support.

\section{Learning points}

- Giant prolactinomas can present with multiple symptoms due to compression of surrounding brain structures.

- Dopamine agonists are the first-line treatment, allowing rapid improvement in symptoms in almost three-fourths of the patients.

- Measuring prolactin immediately on diagnosis of a macroadenoma is mandatory to avoid unnecessary surgery. 
was started on cabergoline $0.5 \mathrm{mg}$ twice weekly, with complete resolution of symptoms and prolactin levels dropping to 377 $\mathrm{mIU} / \mathrm{L}$ at 8 weeks. The MRI scan repeated 2.5 months later showed significant shrinkage in the size of the tumour (figure 2). There was a significant clinical improvement with resolution of most symptoms.

Contributors Concept: MD. Literature search, writing manuscript and collection of images: MFA. Final review: MA and MD.

Funding The authors have not declared a specific grant for this research from any funding agency in the public, commercial or not-for-profit sectors.
Competing interests None declared.

Patient consent Obtained.

Provenance and peer review Not commissioned; externally peer reviewed.

\section{REFERENCES}

1 Maiter D. Current Challenges in the Management of Prolactinomas. Eur Endocrinol 2015:11:39-40.

2 Moraes AB, Silva CM, Vieira Neto L, et al. Giant prolactinomas: the therapeutic approach. Clin Endocrinol 2013;79:447-56.

3 Brisman MH, Fetell MR, Post KD. Reversible dementia due to macroprolactinoma. Case report. J Neurosurg 1993;79:135-7.

Copyright 2018 BMJ Publishing Group. All rights reserved. For permission to reuse any of this content visit

http://group.bmj.com/group/rights-licensing/permissions.

BMJ Case Report Fellows may re-use this article for personal use and teaching without any further permission.

Become a Fellow of BMJ Case Reports today and you can:

- Submit as many cases as you like

- Enjoy fast sympathetic peer review and rapid publication of accepted articles

- Access all the published articles

Re-use any of the published material for personal use and teaching without further permission

For information on Institutional Fellowships contact consortiasales@bmjgroup.com

Visit casereports.bmj.com for more articles like this and to become a Fellow 